\title{
Relationship of Handedness with Second to Fourth Digit (2D: 4D) Ratio and its Role in Sexual Dimorphism in Tibeto-Nepalese and Indo-Nepalese Adult Population of the Dharan Municipality, Sunsari District of Eastern Nepal: An Anthropometric Study
}

\author{
Sandip Shah ${ }^{1}$ Sarun Koirala ${ }^{1} \quad$ Laxman Khanal $^{1}$ \\ ${ }^{1}$ Department of Human Anatomy, B.P Koirala Institute of Health \\ Sciences, Nepal \\ J Morphol Sci 2019;36:33-38.
}

\author{
Address for correspondence Dr Sandip Shah, Associate Professor, \\ Department of Human Anatomy, B.P Koirala Institute of Health \\ Sciences, Nepal, Postal code:56700 \\ (e-mail: sandip.shah@bpkihs.edu; san230dip@yahoo.com).
}

\begin{abstract}
Keywords

- handedness

- lateralization

- tibeto-nepalese

- indo-nepalese

Introduction The importance of handedness lies in its relationship with the lateralization of the brain function, especially of language. The aim of the present study was to provide an authentic database on right and left second to fourth digit (2D:4D) ratios in 2 different ethnic groups of a particular age and gender, and to study its correlation with handedness and sexual dimorphism.

Materials and Methods The present study was conducted among 400 Tibeto-Nepalese (TN) subjects (200 of each gender) and 400 Indo-Nepalese (IN) subjects (200 of each gender) aged $\geq 18$ years old. The values for the $2 \mathrm{D}: 4 \mathrm{D}$ ratio were calculated for both hands. Hand preference was established according to the Edinburgh Handedness Inventory, and five hand preference determination groups were constituted after the calculation of the laterality score. The results were tabulated and subjected to statistical analysis. A pvalue $<0.05$ was considered as statistically significant.

Results The mean value of right sided 2D:4D ratio of TN female was higher as compared to IN female; and for left sided 2D:4D ratio, the value was lower in TN female as compared to IN female. When the values of the $2 \mathrm{D}: 4 \mathrm{D}$ ratios were assessed by gender, the values were found to be statistically significant $(p<0.001)$, whereas when they were assessed by ethnicity, only the right hand 2D:4D ratio was found to be statistically significant $(p<0.001)$.

Conclusion When the relationships between the laterality score and the 2D:4D ratios were examined, the values were found to be statistically significant in both ethnic groups only on the left side. The 2D:4D ratio shows significant ethnic and population differences in the present study.
\end{abstract}

\section{Introduction}

The political scientists Joshi and Rose broadly classify the Nepalese population into three major ethnic groups in terms of their origin: Indo-Nepalese (IN), Tibeto-Nepalese (TN), and
Indigenous (IND). The first group, comprising those of IN origin, inhabits the more fertile lower hills, the river valleys, and the Terai plains adjoining the borders of India. The second major group consists of communities of TN origin occupying the higher hills from the west to the east. ${ }^{1}$ The distribution of received

August 17, 2018

accepted

January 9, 2019

published online

February 15, 2019
DOI https://doi.org/

10.1055/s-0039-1678715. ISSN 2177-0298.
Copyright $\odot 2019$ by Thieme Revinter

Publicações Ltda, Rio de Janeiro, Brazil
License terms

c) $(1) \$$ 
hand preference is J-shaped, reflecting the predominant use of the right hand. ${ }^{2}$ The importance of handedness lies in its relationship with the lateralization of the brain function, especially of language. ${ }^{3}$ The Geschwind-Behan-Galaburda theory states that the influence on early cell loss and prenatal levels of testosterone are related to cerebral lateralization and handedness. ${ }^{4}$ The sexual dimorphism in the 2D:4D ratio is established as early in as the $9^{\text {th }}$ week of fetal life. It is found in children, is little affected by puberty, and appears to be universal in human populations. ${ }^{5-8}$

The main objectives of the present study were:

- To calculate the 2D:4D ratios of both hands of adult individuals from 2 different Nepalese ethnic groups (TN and IN) of both genders.

- To study the correlation of the 2D:4D ratios with handedness or hand preference.

\section{Materials and Methods}

A population-based cross-sectional study was conducted among TN and IN subjects aged $\geq 18$ years old of both genders from the Dharan municipality, in the Sunsari District of Eastern Nepal, using the Edinburgh Handedness Inventory ${ }^{9}$ hand preference determination questionnaire and a separate pre-designed questionnaire for recording sociodemographic variables and length of the second and fourth digits of both hands. The sample size was calculated with an allowable error of $20 \%$ ( $95 \%$ confidence interval [CI]) by using the following formula:

Sample size $(n)=4 \mathrm{pq} / \mathrm{L}^{2}$

In which:

$\mathrm{p}=$ population proportion of positive character,

$\mathrm{q}=1-\mathrm{p}$ and

$\mathrm{L}=$ allowable error.

Hence:

Sample size $(n)=4 \mathrm{pq} / \mathrm{L}^{2}=780$ individuals

Thus, a total of 800 adults ( $\geq 18$ years old) were recruited for the study of both ethnic groups, TN and IN (400 each), including both genders (200 males and 200 females in each ethnic group) by a systematic random sampling technique. The cutoff point for the age of the subjects was the end of January, so all of the participants had to be of a certain age on February 1 st.

\section{Inclusion Criteria}

- Residence in the Dharan Municipality.

\section{Exclusion Criteria}

- Subjects with any apparent physical hand anomalies, inflammation, trauma, deformities and hand surgery

- Subjects with any genetic, psychological, neurological or chronic diseases affecting hand parameters

- Individuals who disagreed to take part in the study

Digit lengths (-Figs. 1, 2) were measured on the ventral surface of the hand from the basal crease of the digit to the tip of the finger using a vernier caliper (Cescorf Equipamentos para Esportes, Porto Alegre, RS, Brazil) with a precision of 0.01

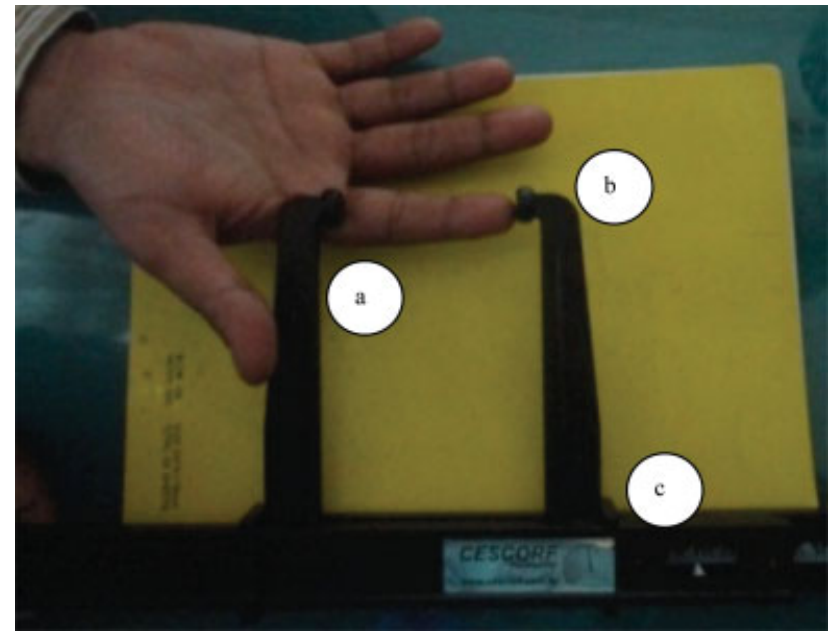

Fig. 1 Measurement of the right $2^{\text {nd }}$ digit length ( $a=$ basal crease; $\mathrm{b}=$ the tip of the finger and $\mathrm{c}=$ vernier caliper (Cescorf Equipamentos para Esportes, Porto Alegre, RS, Brazil)

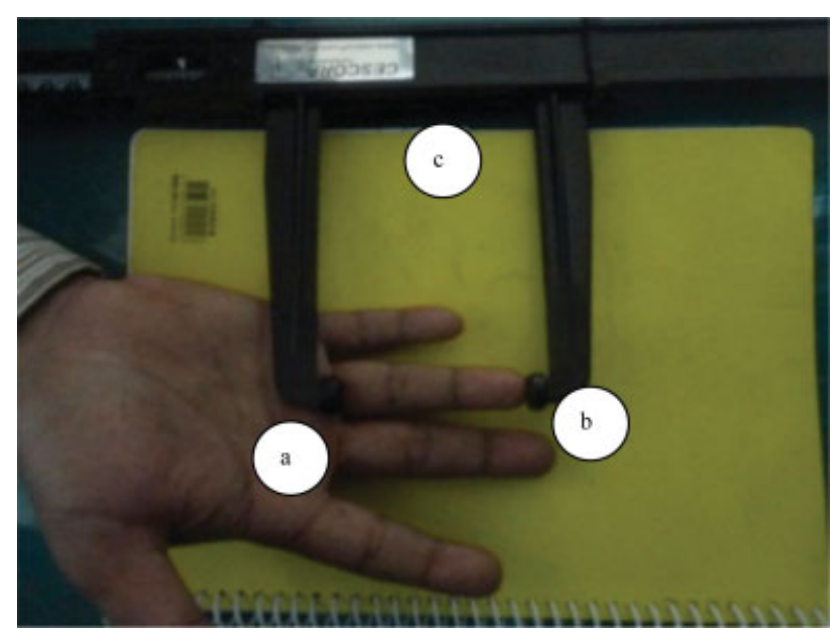

Fig. 2 Measurement of the right $4^{\text {th }}$ digit length( $a=$ basal crease; $b=$ the tip of the finger and $c=$ vernier caliper (Cescorf Equipamentos para Esportes, Porto Alegre, RS, Brazil)

$\mathrm{mm}$. Then, they were reported on the questionnaire and the 2D:4D ratio was calculated. This technique of measuring digit length has been reported to have a high degree of repeatability. ${ }^{10,11}$ Hand preference or handedness was determined according to the Edinburgh Handedness Inventory, which evaluates the direction and the degree of hand preference. ${ }^{9}$

Preinformed written consents were obtained from each respondent, and we have also assured them that their anonymity would be preserved during and after the present study. Ethical clearance for the performance of the present study was taken from the institutional ethical and review board. Participation in the present study was voluntary and the purpose of the study was explained to the participants prior to the distribution of the questionnaires. Permission from the Office of the Dharan municipality was also obtained.

Questions regarding the hand preferences of the participants in: 1) writing; 2) drawing; 3) throwing balls; 4) using scissors; 5) using toothbrush; 6) knife without fork; 7) using 
Table 1 Hand preference were evaluated in 5 groups depending on the value of the Geschwind laterality score

\begin{tabular}{|l|l|l|}
\hline Hand Preference $^{*}$ & Geschwind Score $^{* *}$ & \\
\hline & Minimum value & Maximum value \\
\hline Right hand & & \\
\hline Strong & +80 & +100 \\
\hline Weak & +20 & +75 \\
\hline Ambhidextrous & -15 & +15 \\
\hline Left hand & & \\
\hline Weak & -75 & -20 \\
\hline Strong & -100 & -80 \\
\hline
\end{tabular}

*Hand preference was determined according to the Edinburgh Inventory, which evaluates the direction and the degree of hand preference (Oldfield Rc,1971).

**The resultant sum of these points were used to determine the Geschwind (laterality) score, an indicator of the direction and of the degree of hand preference.

a spoon 8); using a broom 9); striking matches; and 10) opening boxes were asked to the subjects by providing the questionnaire. Subjects had to put a " + " in the column associated with the hand that they was used to carry out each activity. They had to put a " ++ " in the associated column if their preference for one hand was very strong; and to put a "+" in both columns if they used both hand equally. A " ++ " in the right column was assigned 10 points, a " + " in the right column 5 points, a " ++ " in the left column - 10 points, and, a " + " in the left column - 5 points. The resultant sum of these points was used to determine the Geschwind (laterality) score, an indicator of the direction and of the degree of hand preference. The $-100 \leq$ Geschwind score $\leq$ +100 (right hand preference decreases and left hand preference is quantified by Geschwind score, value of which ranges from -100 (strong left hand preference) to +100 (strong right hand preference). Hand preference was evaluated in 5 groups depending on the value of the Geschwind laterality score, as shown in - Table $\mathbf{1}$.

The results were expressed as mean \pm standard deviation (SD). The gender differences in the 2D:4D ratios and in hand preference in each ethnic group were evaluated by an unpaired
Table 3 Interpretation of 2D:4D ratio by gender, hand and ethnic group

\begin{tabular}{|l|l|l|l|l|}
\hline Ethnicity & Hand & Female & Male & $p$-value \\
\hline TN & Right & $1.007 \pm 0.039$ & $1.005 \pm 0.042$ & $<\mathbf{0 . 0 0 1}$ \\
\hline & Left & $0.999 \pm 0.040$ & $1.003 \pm 0.045$ & $<\mathbf{0 . 0 0 1}$ \\
\hline IN & Right & $1.005 \pm 0.024$ & $1.005 \pm 0.044$ & 0.686 \\
\hline & Left & $1.001 \pm 0.031$ & $1.003 \pm 0.045$ & $\mathbf{0 . 0 4}$ \\
\hline
\end{tabular}

Abbreviations: 2D:4D, second to fourth digit ration; IN, Indo-Nepalese; TN,Tibeto-Nepalese.

Results are shown as mean \pm standard deviation, with $p$-value.

$t$-test. The right-left differences in 2D:4D ratios (2D:4D right hand - 2D:4D left hand) in each gender and ethnic group were evaluated by an unpaired $t$-test. The differences of laterality in the 2D:4D ratios, taking into account the hand preference, were evaluated by the paired student $t$-test. A $p<0.05$ was considered statistically significant. The correlation between the hand preference and the 2D:4D ratios were evaluated by the Pearson correlation coefficient ( $r$ ) analysis. Statistical analyses were performed using SPSS Statistics for Windows, Version 11.4 (SPSS Inc., Chicago, IL, USA).

\section{Results}

In the present study, $82 \%$ of the TN males were found to have a strong right hand (SRH) whereas $82.5 \%$ of the TN females were found to have a SRH, followed by $10 \%$ and $12.5 \%$ strong left hand (SLH) in males and females, respectively, whereas in IN males and females, SRH were $86 \%$, followed by $10 \%$ and $12.5 \%$ SLH in males and females, respectively (- Table 2 ). The 2D:4D ratio of the TN subjects in both hands of both genders were found be statistically significant $(p<0.001)$. However, in the IN subjects of both genders, only the left side 2D:4D ratio was found be statistically significant $(p<0.001)$ ( - Table 3).The right-left difference by gender in each group were found be statistically significant $(p<0.001)$ ( - Table 4 ). The right-left 2D:4D ratios in the 5 groups evaluated by hand preference in the TN population were found to be not statistically significant $(p>0.05)$ ( - Table 5). The right-left 2D:4Ds ratios in SRH and SLH TN males were found be

Table 2 Distribution of subjects by hand preference and gender

\begin{tabular}{|l|l|l|l|l|l|}
\hline Hand preference & $\begin{array}{l}\text { TN male } \\
n(\%)\end{array}$ & $\begin{array}{l}\text { TN female } \\
\boldsymbol{n}(\%)\end{array}$ & $\begin{array}{l}\text { IN Male } \\
\boldsymbol{n}(\%)\end{array}$ & $\begin{array}{l}\text { IN female } \\
\boldsymbol{n}(\%)\end{array}$ \\
\hline Strong right hand & $164(82)$ & $165(82.5)$ & $172(86)$ & $172(86)$ & $673(84)$ \\
\hline Weak right hand & $13(6.5)$ & $9(4.5)$ & $8(4)$ & $2(1)$ & $32(4)$ \\
\hline Ambidextrous hand & 0 & $1(0.5)$ & 0 & 0 & $1(0.5)$ \\
\hline Weak left hand & $3(1.5)$ & 0 & 0 & $25(12.5)$ & $4(0.1)$ \\
\hline Strong left hand & $20(10)$ & $25(12.5)$ & $20(10)$ & $200(25)$ & $90(11.2)$ \\
\hline Total & $200(25)$ & $200(25)$ & $200(25)$ & & $800(100)$ \\
\hline
\end{tabular}

Abbreviations: IN, Indo-Nepalese; IND, Indigenous; TN,Tibeto-Nepalese.

Results are shown as number and percentage of frequency. 
Table 4 Right-Left difference by gender in each group

\begin{tabular}{|l|l|l|l|}
\hline Ethnicity & Male & Female & $p$-value \\
\hline TN & $-0.0021 \pm 0.044$ & $0.0012 \pm 0.053$ & $<\mathbf{0 . 0 0 1}$ \\
\hline IN & $0.0021 \pm 0.036$ & $0.0012 \pm 0.029$ & $<\mathbf{0 . 0 0 1}$ \\
\hline
\end{tabular}

Abbreviations: 2D:4D, second to fourth digit ratio; IN, Indo-Nepalese; TN,Tibeto-Nepalese.

Results are shown as mean \pm standard deviation, with p-value.

Table 5 Right-Left 2D:4D ratio in five groups evaluated by hand preference in Tibeto-Nepalese

\begin{tabular}{|l|l|l|l|}
\hline Handedness & Right & Left & $p$-value \\
\hline SRH & $1.0032 \pm 0.041$ & $1.0033 \pm 0.042$ & $>0.05$ \\
\hline WRH & $0.979 \pm 0.52$ & $0.997 \pm 0.48$ & $>0.05$ \\
\hline AMBH & 0.984 & 0.857 & -- \\
\hline WLH & $0.998 \pm 0.097$ & $0.967 \pm 0.41$ & $>0.05$ \\
\hline SLH & $1.0049 \pm 0.043$ & $1.0047 \pm 0.033$ & $>0.05$ \\
\hline
\end{tabular}

Abbreviations: 2D:4D, second to fourth digit ratio; $\mathrm{AMBH}$, ambidextrous; SLH, strong left hand; SRH,strong right hand; WLH, weak left hand; WRH, weak right hand.

Results are shown as mean \pm standard deviation, with $p$-value.

Table 6 Right-Left 2D:4D ratio in 5 groups evaluated by hand preference in Tibeto-Nepalese by gender

\begin{tabular}{|l|l|l|l|l|}
\hline Gender & Handedness & Right & Left & $p$-value \\
\hline Male & SRH & $\begin{array}{l}1.0033 \pm \\
0.0421\end{array}$ & $\begin{array}{l}1.0056 \pm \\
0.0416\end{array}$ & $<0.001$ \\
& & $0.9914 \pm$ & $1.0014 \pm$ & 0.581 \\
& WRH & 0.054 & 0.052 & \\
\hline & WLH & $0.9882 \pm$ & $0.9677 \pm$ & 0.71 \\
& & 0.097 & 0.041 & \\
\hline & SLH & $1.0121 \pm$ & $1.0132 \pm$ & $<\mathbf{0 . 0 0 1}$ \\
& & 0.061 & 0.044 & \\
\hline Female & SRH & $\begin{array}{l}1.0032 \pm \\
0.041\end{array}$ & $\begin{array}{l}1.0013 \pm \\
0.041\end{array}$ & 0.151 \\
& & $0.9624 \pm$ & $0.9920 \pm$ & 0.601 \\
\hline & WRH & 0.046 & 0.043 & \\
\hline & & 0.9848 & 0.8571 & -- \\
\hline & AMBH & $0.9992 \pm$ & $0.9979 \pm$ & 0.623 \\
& & 0.0228 & 0.0214 & \\
\hline
\end{tabular}

Abbreviations: 2D:4D, second to fourth digit ratio; $\mathrm{AMBH}$, ambidextrous; SLH, strong left hand; SRH,strong right hand; WLH, weak left hand; WRH, weak right hand.

Results are shown as mean \pm standard deviation, with $p$-value.

statistically significant $(p<0.001)$ ( - Table 6 ). The right-left 2D:4D ratios in SRH and in weak right hand (WRH) of IN subjects were found be statistically significant $(p<0.001)$ ( - Table 7). The right-left 2D:4D ratios in SRH IN males and in SRH, WRH, and SLH in IN females were found be statistically significant $(p<0.001)$ (-Table 8). The right 2D:4D ratio in WRH ( $p=0.007)$ and in SLH $(p=0.048)$ groups in males in both ethnic groups were found be statistically significant ( - Table 9). The right 2D:4D ratio in SRH $(p<0.001)$ and the
Table 7 Right-Left 2D:4D ratio in 5 groups evaluated by hand preference in Indo-Nepalese

\begin{tabular}{|l|l|l|l|}
\hline Handedness & Right & Left & $p$-value \\
\hline SRH & $1.0034 \pm 0.036$ & $1.0023 \pm 0.038$ & 0.04 \\
\hline WRH & $0.998 \pm 0.023$ & $1.027 \pm 0.077$ & $<0.001$ \\
\hline AMBH & 0 & 0 & -- \\
\hline WLH & 1.109 & 0.939 & -- \\
\hline SLH & $0.9976 \pm 0.031$ & $0.998 \pm 0.022$ & $>0.05$ \\
\hline
\end{tabular}

Abbreviations: 2D:4D, second to fourth digit ratio; $\mathrm{AMBH}$, ambidextrous; $\mathrm{SLH}$, strong left hand; SRH,strong right hand; $\mathrm{WLH}$, weak left hand; WRH, weak right hand.

Results are shown as mean \pm standard deviation, with p-value.

Table 8 Right-Left 2D:4D ratio in 5 groups evaluated by hand preference in Indo-Nepalese by gender

\begin{tabular}{|c|c|c|c|c|}
\hline Gender & Handedness & Right & Left & $p$-value \\
\hline \multirow[t]{3}{*}{ Male } & SRH & $\begin{array}{l}1.0069 \pm \\
0.046\end{array}$ & $\begin{array}{l}1.0034 \pm \\
0.047\end{array}$ & $<0.001$ \\
\hline & WRH & $\begin{array}{l}1.0027 \pm \\
0.021\end{array}$ & $\begin{array}{l}1.0076 \pm \\
0.047\end{array}$ & 0.875 \\
\hline & SLH & $\begin{array}{l}0.9909 \pm \\
0.037\end{array}$ & $\begin{array}{l}0.9977 \pm \\
0.025\end{array}$ & 0.287 \\
\hline \multirow[t]{4}{*}{ Female } & SRH & $\begin{array}{l}0.9998 \pm \\
0.023\end{array}$ & $\begin{array}{l}1.0011 \pm \\
0.028\end{array}$ & $<0.001$ \\
\hline & WRH & $\begin{array}{l}0.9797 \pm \\
0.028\end{array}$ & $\begin{array}{l}1.107 \pm \\
0.151\end{array}$ & $<0.001$ \\
\hline & WLH & 1.1093 & 0.9393 & -- \\
\hline & SLH & $\begin{array}{l}1.002 \pm \\
0.0255\end{array}$ & $\begin{array}{l}0.999 \pm \\
0.199\end{array}$ & $<0.001$ \\
\hline
\end{tabular}

Abbreviations: 2D:4D, second to fourth digit ratio; SLH, strong left hand; SRH,strong right hand; WLH, weak left hand; WRH, weak right hand. Results are shown as mean \pm standard deviation, with $p$-value.

right 2D:4D ratio in WRH $(p=0.011)$ groups in females in both ethnic groups were found be statistically significant (-Table 10). A positive correlation between the Geschwind score and the 2D:4D ratio was found in both ethnic groups, but this correlation was significant only in the right 2D:4D ratio of both ethnic groups $(<0.001$ level; 2-tailed) (-Table 11).

\section{Discussion}

The differences in hand preferences may be linked to the prenatal production of testosterone and estradiol and, in the case of testosterone, to interactions with the homeobox genes Hoxa and Hoxd, which control the differentiation of the urogenital system and the development of the digits. ${ }^{12}$ It is generally agreed in previous studies that $2 \mathrm{D}: 4 \mathrm{D}$ ratios tend to be greater in females (closer to 1.0), and that gender differences tend to be larger for the right hand than for the left. However, in the present study, only IN females had a greater ratio than males. ${ }^{13,14}$ - Table 12 shows the comparative evaluation of the $2 \mathrm{D}: 4 \mathrm{D}$ ratios between the present study and previous studies. 
Relationship of Handedness with Second to Fourth Digit (2D: 4D) Ratio Shah et al. 37

Table 9 Right-Left 2D:4D ratio in 5 groups evaluated by hand preference in males in both ethnic groups

\begin{tabular}{|c|c|c|c|c|}
\hline Handedness & $\begin{array}{l}\text { Right/ } \\
\text { Left }\end{array}$ & TN & IN & $p$-value \\
\hline \multirow[t]{2}{*}{ SRH } & Right & $\begin{array}{l}1.0033 \pm \\
0.0421\end{array}$ & $\begin{array}{l}1.0069 \pm \\
0.046\end{array}$ & 0.831 \\
\hline & Left & $\begin{array}{l}1.0056 \pm \\
0.0416\end{array}$ & $\begin{array}{l}1.0034 \pm \\
0.047\end{array}$ & 0.821 \\
\hline \multirow[t]{2}{*}{ WRH } & Right & $\begin{array}{l}0.9914 \pm \\
0.054\end{array}$ & $\begin{array}{l}1.0027 \pm \\
0.021\end{array}$ & 0.007 \\
\hline & Left & $\begin{array}{l}1.0014 \pm \\
0.052\end{array}$ & $\begin{array}{l}1.0076 \pm \\
0.047\end{array}$ & 0.466 \\
\hline \multirow[t]{2}{*}{ WLH } & Right & $\begin{array}{l}0.9882 \pm \\
0.097\end{array}$ & ......... & $\ldots .$. \\
\hline & Left & $\begin{array}{l}0.9677 \pm \\
0.041\end{array}$ & .......... & $\ldots .$. \\
\hline \multirow[t]{2}{*}{ SLH } & Right & $\begin{array}{l}1.0121 \pm \\
0.061\end{array}$ & $\begin{array}{l}0.9909 \pm \\
0.037\end{array}$ & 0.048 \\
\hline & Left & $\begin{array}{l}1.0132 \pm \\
0.044\end{array}$ & $\begin{array}{l}0.9977 \pm \\
0.025\end{array}$ & 0.064 \\
\hline
\end{tabular}

Abbreviations: 2D:4D, second to fourth digit ratio; IN, Indo-Nepalese; $\mathrm{SLH}$, strong left hand; SRH,strong right hand; TN, Tibeto-Nepalese; WLH, weak left hand; WRH, weak right hand.

Results are shown as mean \pm standard deviation, with $p$-value.

Table 10 Right-Left 2D:4D ratio in 5 groups evaluated by hand preference in females in both ethnic groups

\begin{tabular}{|c|c|c|c|c|}
\hline Handedness & $\begin{array}{l}\text { Right/ } \\
\text { Left }\end{array}$ & TN & IN & $p$-value \\
\hline \multirow[t]{2}{*}{ SRH } & Right & $\begin{array}{l}1.0032 \pm \\
0.041\end{array}$ & $\begin{array}{l}0.9998 \pm \\
0.023\end{array}$ & $<0.001$ \\
\hline & Left & $\begin{array}{l}1.0013 \pm \\
0.041\end{array}$ & $\begin{array}{l}1.0011 \pm \\
0.028\end{array}$ & 0.06 \\
\hline WRH & Right & $\begin{array}{l}0.9624 \pm \\
0.046\end{array}$ & $\begin{array}{l}0.9797 \pm \\
0.028\end{array}$ & 0.282 \\
\hline AMBHI & $\begin{array}{l}\text { Left } \\
\text { Right } \\
\text { Left }\end{array}$ & $\begin{array}{l}0.9920 \pm \\
0.043 \\
0.9848 \\
0.8571\end{array}$ & $\begin{array}{l}1.107 \pm \\
0.151 \\
\ldots \ldots \ldots . . \\
\ldots \ldots \ldots \ldots\end{array}$ & $\begin{array}{l}0.011 \\
\ldots \ldots . . \\
\ldots \ldots \ldots .\end{array}$ \\
\hline \multirow[t]{2}{*}{ WLH } & Right & ............ & 1.1093 & $\ldots .$. \\
\hline & Left & …....... & 0.9393 & $\ldots .$. \\
\hline \multirow[t]{2}{*}{ SLH } & Right & $\begin{array}{l}0.9992 \pm \\
0.0228\end{array}$ & $\begin{array}{l}1.002 \pm \\
0.0255\end{array}$ & 0.373 \\
\hline & Left & $\begin{array}{l}0.9979 \pm \\
0.0214\end{array}$ & $\begin{array}{l}0.999 \pm \\
0.199\end{array}$ & 0.972 \\
\hline
\end{tabular}

Abbreviations: 2D:4D, second to fourth digit ratio; IN, Indo-Nepalese; $\mathrm{SLH}$, strong left hand; SRH,strong right hand; TN, Tibeto-Nepalese; WLH, weak left hand; WRH, weak right hand.

Results are shown as mean \pm standard deviation, with $p$-value.

\section{Conclusion}

In the present study, $82 \%$ of TN males were found to be SRH, whereas $82.5 \%$ of TN females were found be SRH, followed, by $10 \%$ and $12.5 \%$ SLH in males and females, respectively. The 2D:4D ratio showed significant ethnic and population differences.
Table 11 Relationship between G- score and 2D:4D ratio

\begin{tabular}{|l|l|l|}
\hline Ethnic group & 2D:4D ratio & Coefficent of correlation\# \\
\hline TN & Right & $0.573^{* *}$ \\
\hline & Left & 0.093 (NS) \\
\hline IN & Right & $0.348^{* *}$ \\
\hline & Left & 0.084 (NS) \\
\hline
\end{tabular}

Abbreviations: 2D:4D, second to fourth digit ratio; IN, Indo-Nepalese; NS, Not significant; TN, Tibeto-Nepalese.

\#Correlation is significant at a level $<0.001$ (2-tailed).

Table 12 Comparative evaluation of 2D:4D ratios in males and in females in different studies

\begin{tabular}{|c|c|c|c|c|}
\hline Author & Population & $n$ & Gender & 2D:4D \\
\hline $\begin{array}{l}\text { Manning et al } \\
(1998)^{10}\end{array}$ & English & 400 & $\begin{array}{l}M \\
F\end{array}$ & $\begin{array}{l}0.98 \\
1.00\end{array}$ \\
\hline $\begin{array}{l}\text { William et al } \\
(2000)^{15}\end{array}$ & American & $\begin{array}{l}108 \\
146\end{array}$ & $\begin{array}{l}M \\
F\end{array}$ & $\begin{array}{l}0.96 \\
0.97\end{array}$ \\
\hline $\begin{array}{l}\text { Swami et al } \\
(2013)^{16}\end{array}$ & $\begin{array}{l}\text { Harayani Brahmins } \\
\text { Kashmiris pandits }\end{array}$ & $\begin{array}{l}150 \\
150\end{array}$ & $\begin{array}{l}M \\
F \\
M \\
F\end{array}$ & $\begin{array}{l}0.95 \\
0.98 \\
0.99 \\
1.001\end{array}$ \\
\hline $\begin{array}{l}\text { Present } \\
\text { study }\end{array}$ & $\begin{array}{l}\text { Tibeto-Nepalese } \\
\text { Indo-Nepalese }\end{array}$ & $\begin{array}{l}200 \\
200\end{array}$ & $\begin{array}{l}M \\
F \\
M \\
F\end{array}$ & $\begin{array}{l}1.004 \\
0.99 \\
1.003 \\
1.004\end{array}$ \\
\hline
\end{tabular}

Abbreviations: 2D:4D, second to fourth digit ratio; $F$, female; $M$, male.

\section{Financial Support}

The present study received a research grant from the B. P. Koirla Institute of Health Sciences.

Conflicts of Interest

The authors have no conflicts of interest to declare.

\section{Acknowledgments}

We would like to thank Dr. Bhawesh Koirala for helping us during the data collection. We would like to acknowledge the B. P. Koirla Institute of Health Sciences, the Office of the Dharan Municipality, and the Institutional review committee (IRC) for their support and for allowing us to perform the present research.

\section{References}

1 JOSHI \& ROSE. “Nepal-Caste and Ethnicity” [Internet];1991, Available from http://countrystudies.us/nepal/31.htm. Accessed on $7^{\text {th }}$ April 2018.

2 Annett M. Handedness and brain asymmetry: The Right Shift Theory. Hove: Psychology Press; 2002

3 Beaton AA. The nature and determinants of handedness. In: Hugdahl K, Davidson RJ (Eds.). The asymmetrical brain. Cambridge, MA: MIT Press; 2003:105-158

4 Geschwind N, Galaburda A. Cerebral lateralization. Cambridge, MA: MIT Press; 1986

5 Malas MA, Dogan S, Evcil EH, Desdicioglu K. Fetal development of the hand, digits and digit ratio (2D:4D). Early Hum Dev 2006;82 (07):469-475 
38 Relationship of Handedness with Second to Fourth Digit (2D: 4D) Ratio Shah et al.

6 Manning JT, Stewart A, Bundred PE, Trivers RL. Sex and ethnic differences in 2nd to 4th digit ratio of children. Early Hum Dev 2004;80(02):161-168

7 Manning JT, Churchill AJ, Peters M. The effects of sex, ethnicity, and sexual orientation on self-measured digit ratio (2D:4D). Arch Sex Behav 2007;36(02):223-233

8 McIntyre MH, Ellison PT, Lieberman DE, Demerath E, Towne B. The development of sex differences in digital formula from infancy in the Fels Longitudinal Study. Proc Biol Sci 2005;272 (1571):1473-1479

9 Oldfield RC. The assessment and analysis of handedness: the Edinburgh inventory. Neuropsychologia 1971;9(01):97-113

10 Manning JT, Scutt D, Wilson J, Lewis-Jones DI. The ratio of 2nd to 4th digit length: a predictor of sperm numbers and concentrations of testosterone, luteinizing hormone and oestrogen. Hum Reprod 1998;13(11):3000-3004
11 Danborno B, Danborno AM. The effect of the seasonof birth and fluctuating asymmetry on second and fourth digit lengths and digit ratio (2D:4D) in Nigerians. Eur J Zool Res 2015;4(01):7-11

12 Mortlock DP, Innis JW. Mutation of HOXA13 in hand-foot-genital syndrome. Nat Genet 1997;15(02):179-180

13 Brown WM, Finn CJ, Cooke B, Breedlove SM. Differences in finger length ratios between self-identified 'butch' and 'femme' lesbians. Arch Sex Behav •••;200231:123-127

14 McFadden D, Shubel E. Relative lengths of fingers and toes in human males and females. Horm Behav 2002;42(04):492-500

15 Williams TJ, Pepitone ME, Christensen SE, et al. Finger-length ratios and sexual orientation. Nature 2000;404(6777):455-456

16 Swami S, Kumar T. Sharma \& Kausal S.Effect of hand preference on second to fourth digit ratio and its role in sexual dimorphism: a study in 300 Haryanvi Brahmins and 300 Kashmiri Pandits. Eur J Anat 2013;17(04):243-249 